\title{
PENGARUH SELF-KNOWLEDGE DAN SELF-DECEPTION TERHADAP PENGELOLAAN UANG SAKU
}

\author{
Ari Wahyu Leksono ${ }^{1}$, Rendika Vhalery ${ }^{2}$ \\ Pendidikan Ekonomi, FIPPS, Universitas Indraprasta PGRI Jakarta \\ Ariwahyu.leksono@unindra.ac.id ${ }^{1}$,rendika.vhalery@unindra.ac.id ${ }^{2}$
}

\begin{abstract}
Abstrak
Fenomena mengelola uang saku dikalangan remaja menjadi suatu topik yang menarik untuk dikaji. Kajian ini akan lebih menarik apabila dilihat dari sisi internal seperti faktor diri (self). Ada banyak jenis diri individu, diantaranya yaitu self-knowledge sebagai pengetahuan diri dan self-deception sebagai manipulasi/kebohongan diri. Penelitian ini bertujuan untuk mengetahui apakah selfknowledge dan self-deception berpengaruh terhadap pengelolaan uang saku. Penelitian ini melibatkan 219 mahasiswa Universitas Indraprasta PGRI Jakarta. Teknik pengumpulan data menggunakan angket yang disebarkan secara langsung dan secara tidak langsung (via google form) yang dianalisis menggunakan regresi linear berganda. Hasil menunjukkan bahwa; terdapat pengaruh signifikan self-knowledge terhadap pengelolaan uang saku, terdapat pengaruh negatif signifikan self-deception terhadap pengelolaan uang saku, dan terdapat pengaruh self-knowledge dan self-deception terhadap pengelolaan uang saku.
\end{abstract}

Kata kunci: self-knowledge; self-deception; pengelolaan uang saku

\section{PENDAHULUAN}

Pengelolaan uang saku anak-anak Indonesia sangat menarik untuk dikaji. Hal ini disebabkan oleh perilaku mereka yang sulit untuk diprediksi. Sebagian besar dari mereka kurang maksimal dalam menggunakan uang saku dan sebagian yang lain dapat mengelola namun tidak mampu bertanggung jawab (Vhalery, Aimon, \& Yulhendri, 2018). Akibatnya, perilaku mereka ketika menggunakan uang saku tidak terkontrol dan boros (Vhalery, Aimon, et al., 2018; Vhalery, Leksono, \& Moh. Irvan, 2019). Dikhawatirkan, perilaku ini akan terus berlanjut dan berdampak buruk pada keuangan mereka di masa depan (Bucciol \& Veronesi, 2014; Otto, 2013).

Untuk mengetahui perilaku pengelolaan uang saku secara langsung, peneliti melakukan studi awal lapangan dengan melakukan wawancara. Hasil wawancara secara keseluruhan mengungkapkan bahwa ada tiga tipe individu dalam mengelola uang saku. Pertama, mampu mengelola uang saku dengan sangat baik tanpa arahan maupun bantuan seseorang. Kedua, mampu mengelola uang saku dengan baik namun butuh masukan dari teman atau orang tua. Ketiga, kurang 
Research and Development Journal Of Education

Vol. 6 No. 1 Oktober 2019

p-ISSN 2406-9744

e-ISSN 2657-1056

mampu mengelola uang saku dengan baik dikarenakan kurangnya informasi atau pengalaman dalam mengelola uang saku.

Ada banyak faktor yang mempengaruhi pengelolaan uang saku dari sisi internal (Vhalery, Leksono, \& Moh. Irvan, 2018). Salah satu faktor internal yang mempengaruhi pengelolaan uang saku diantaranya aspek psikologi (Otto, 2013). Aspek psikologi khusus yang menarik untuk dikaji adalah faktor diri (self) seperti self-knowledge (pengetahuan diri) dan self-deception (kebohongan/penipuan diri). Self-knowledge memiliki implikasi etis yang menyiratkan tanggung jawab (Fuchs \& Hofkirchner, 2005), dengan mempertimbangkan nilai-nilai sebagai pengaruh penting sehingga berdampak positif atau konstruktif (Begley, 2006). Sedangkan self-deception menandakan ketidakmampuan untuk menilai secara objektif pada suatu fenomena dan terlepas dari kenyataan (atau bertentangan) yang sebenarnya (Bachkirova, 2016).

Konseptualisasi "self-knowledge" diartikan sebagai "intisari diri" dalam merepresentasikan diri secara aktual atau diri yang diinginkan (dan tidak diinginkan) yang memotivasi berbagai jenis pengaturan diri (baik dalam gerakan maupun pencegahan) yang berfokus dalam melakukan sesuatu aktivitas keuangan (Woo, Boland, \& Cooperrider, 2017). Self-knowledge membantu individu dalam bertindak berdasarkan pengetahuan untuk mengelola keuangan (Fuchs \& Hofkirchner, 2005). Seseorang dengan self-knowledge tinggi dapat memproses perilaku keuangan dengan baik. Sedangkan seseorang dengan self-knowledge rendah, kurang maksimal dalam mengaplikasikan perilaku keuangannya. Oleh sebab itu, self-knowledge sangat membantu dalam mengelola uang saku.

Self lainnya yaitu self-deception yang merupakan manipulasi diri atau kebohongan diri atau penipuan diri. Menurut Tully \& Bailey (2017) self-deception merupakan permasalahan pada penilaian diri berdasarkan pertimbangan individu. Self-deception pada pengelolaan uang dapat bernilai positif apabila digunakan pada saat yang tepat. Seperti seseorang yang tahu risiko namun cenderung percaya diri untuk meningkatkan motivasi dalam mengambil keputusan keuangan yang tepat (Leung, 2010). Self-deception juga dapat bernilai negatif apabila individu cenderung terlalu percaya diri dan melakukan kesalahan penilaian (Leung, 2010), atau tindakan yang berlawaan dengan prinsip-prinsip moral untuk mendapatkan keuntungan (Gomes \& Frade, 2019). Jadi, pemanfaatan self-deception pada 
Research and Development Journal Of Education

Vol. 6 No. 1 Oktober 2019

p-ISSN 2406-9744

e-ISSN 2657-1056

pengelolaan uang saku bernilai positif atau negatif tergantung pada individu yang memanfaatkannya.

Penelitian pengelolaan uang saku ini merupakan penelitian lanjutan dari penelitian yang pernah dilakukan oleh peneliti, seperti faktor-faktor yang mempengaruhi pengelolaan uang saku mahasiswa (Vhalery, Leksono, et al., 2018), pengaruh lingkungan keluarga, teman sebaya, jenis kelamin, dan kontrol diri terhadap pengelolaan uang saku pelajar (Vhalery, Aimon, et al., 2018), dan pengaruh literasi keuangan, usia, dan bimbingan orang tua terhadap pengelolaan uang saku mahasiswa unindra (Vhalery et al., 2019). Penelitian lanjutan ini dilakukan untuk mengeksplorasi lebih lanjut tentang faktor lain yang mempengaruhi uang saku. Oleh karena itu, peneliti tertarik untuk melakukan penelitian yang berjudul "Pengaruh Self-Knowledge Dan Self-Deception Terhadap Pengelolaan Uang Saku".

\section{TINJAUAN PUSTAKA}

\section{Self-knowledge pada Aktivitas Pengelolaan Uang Saku}

Self-knowledge atau pengetahuan diri merupakan dasar pengetahuan dan kondisi psikologis yang tersirat didalam diri manusia yang berpusat pada inti otak. Fuchs \& Hofkirchner (2005) mendefinisikan self-knowledge sebagai manifestasi dari informasi dalam ranah kognitif-afektif individu untuk mengatur diri sendiri. Informasi tersebut dirangsang oleh pengaruh internal dan eksternal yang akan diproses untuk memandu sikap (Woo et al., 2017), atau diperlukan individu untuk membuat atau mengambil keputusan yang tepat (Glanz \& Sluis, 2001; Woo et al., 2017). Selain itu, self-knowledge juga dapat memberikan keyakinan dan informasi yang benar sebagai aliran pesan pada suatu aktivitas dalam upaya penciptaan pengetahuan baru yang dianggap mengandung interpretasi (Laihonen, 2006), berdasarkan asas lima dimensi yaitu dimensi interior, dimensi subjektif, dimensi transformasi, dimensi sosial, dan dimensi tindakan (Shumack, 2007).

Self-knowledge pada keterampilan mengelola uang saku berfokus pada pengembangan individu berdasarkan informasi dirinya dan pemanfaatan keterampilan yang terkait dengan manajemen dirinya, contohnya mengatur, mengendalikan, dan mengontrol uang saku berdasarkan pengetahuan (Anakwe, Hall, \& Schor, 2000). Selain itu, self-knowledge yang telah terbentuk 
Research and Development Journal Of Education

Vol. 6 No. 1 Oktober 2019

p-ISSN 2406-9744

e-ISSN 2657-1056

menunjukkan interaksi antara self-knowledge dengan pengelolaan uang saku yang merujuk pada pembentukan atau penggalian pengalaman hidup, pelatihan profesional, refleksi, membangun keterikatan dan konteks antara unsur motivasi dengan nilai-nilai spesifik yang diadopsi oleh individu (Begley, 2006). Singkatnya, kemampuan ini membentuk pengetahuan diri, pengetahuan interpersonal, dan pengetahuan lingkungan secara umum diakui untuk mendorong pengelolaan uang saku yang efektif untuk meningkatkan hasil yang optimal (Anakwe et al., 2000).

Self-knowledge pada pengelolaan uang saku diperlukan untuk mempersiapkan individu "untuk belajar cara belajar" tentang mengenali kapasitas diri, kemampuan beradaptasi, peningkatan kemampuan mengendalikan uang saku (Anakwe et al., 2000). Secara umum, pola keterikatan antara self-knowledge dan pengelolaan uang saku dapat digambarkan secara ringkas pada konsep berikut ini:

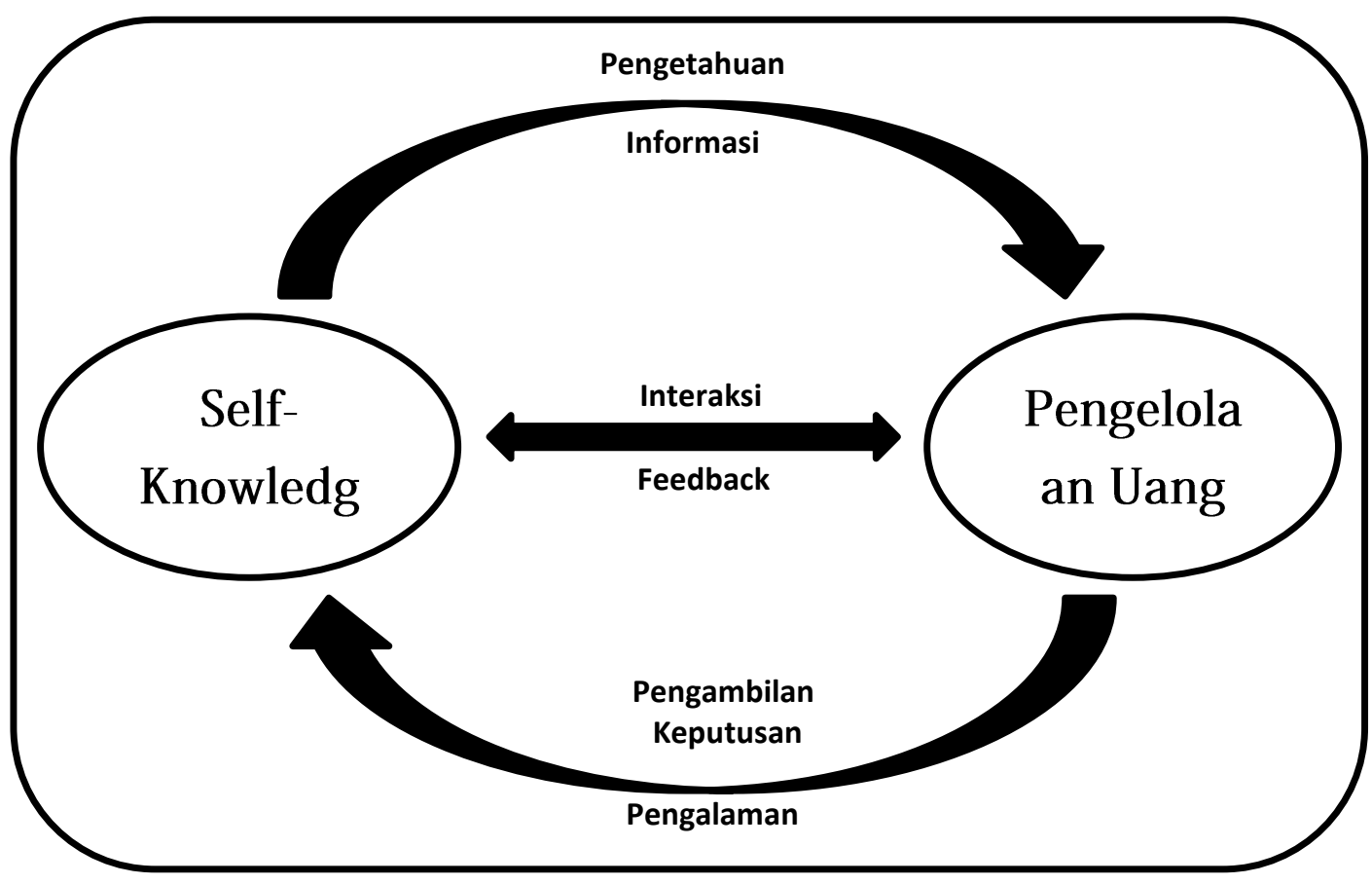

Gambar 1. Konsep Interaksi antara Self-knowledge dan Pengelolaan Uang Saku $\mathrm{Ha}_{1}$ : Terdapat pengaruh self-knowledge terhadap pengelolaan uang saku

\section{Self-deception pada Aktivitas Pengelolaan Uang Saku}

Self-deception adalah tindakan yang bertolak belakang dengan kejadian yang sebenarnya untuk menutupi suatu maksud dan/atau tujuan. Self-deception berkaitan dengan kesederhanaan kognitif dan megalomania (Triandis, 2015). 
Research and Development Journal Of Education

Vol. 6 No. 1 Oktober 2019

p-ISSN 2406-9744

e-ISSN 2657-1056

Menurut Scott (2012), Self-deception adalah tindakan pengkhianatan yang secara moral dapat disalahkan. Karena memanipulasi harapan, kebutuhan, dan keinginan untuk mencapai tujuan individu (Leung, 2010; Triandis, 2015). Lebih lanjut, Gomes \& Frade (2019) menambahkan bahwa self-deception berkaitan dengan distorsi atau manipulasi realitas dengan maksud membuat orang bertindak dengan cara yang tidak bermanfaat bagi kepentingan mereka sendiri. Sedangkan Kuntz \& Dehlin (2019), melihat self-deception sebagai fenomena yang dimotivasi oleh alam bawah sadar, yang dihasilkan dari interaksi yang berkelanjutan antara faktorfaktor intrapersonal dan relasional dalam lingkungan yang terorganisir. Dapat disimpulkan bahwa self-deception merupakan tindakan manipulasi (berbohong atau menipu) yang bertujuan untuk mencapai kepentingan individu.

Self-deception pada pengelolaan uang saku mempunyai 2 persepsi yaitu selfdeception sebagai teman atau self-deception sebagai musuh (Kuntz \& Dehlin, 2019), dengan bentuk yang strategis atau gagasan yang muncul dari kegagalan rasionalitas (Gomes \& Frade, 2019). Self-deception sebagai teman menjadikan kebohongan sebagai suatu keyakinan untuk mendukung aktivitas pengelolaan uang saku (Leung, 2010). Aktivitas ini menunjukkan keterlibatan antara keyakinan dan kemampuan mengatur uang saku pada tindakan dan proses yang bias namun konstruktivis untuk menarik perhatian pada hasil yang ingin dicapai (Bachkirova, 2016; Dings, 2017; Kuntz \& Dehlin, 2019). Sedangkan selfdeception sebagai musuh dilakukan untuk menyesatkan diri sendiri atau orang lain (Meltzer, 2003). Aktivitas self-deception sebagai musuh pada diri sendiri seperti: cenderung menyukai informasi positif dan menolak informasi negatif untuk memanipulasi informasi (Triandis, 2015). Contohnya: seseorang akan mencari informasi tentang mengelola uang saku yang baik namun mengelola uang secara kurang baik, untuk dirinya atau membagikan informasi kepada temannya. Secara mendalam, tindakan self-deception ini pada perilaku mengelola uang menjadi usaha yang tidak murni dan menjadi lebih emosional (timbul perasaan bersalah dalam mengendalikan keuangan) atau lepas kontrol (Scott, 2012).

Mereka mungkin menggambarkan diri mereka secara positif atau berlebihan karena mereka kurang wawasan dan sebenarnya terlibat dalam penipuan diri (Tully \& Bailey, 2017) 


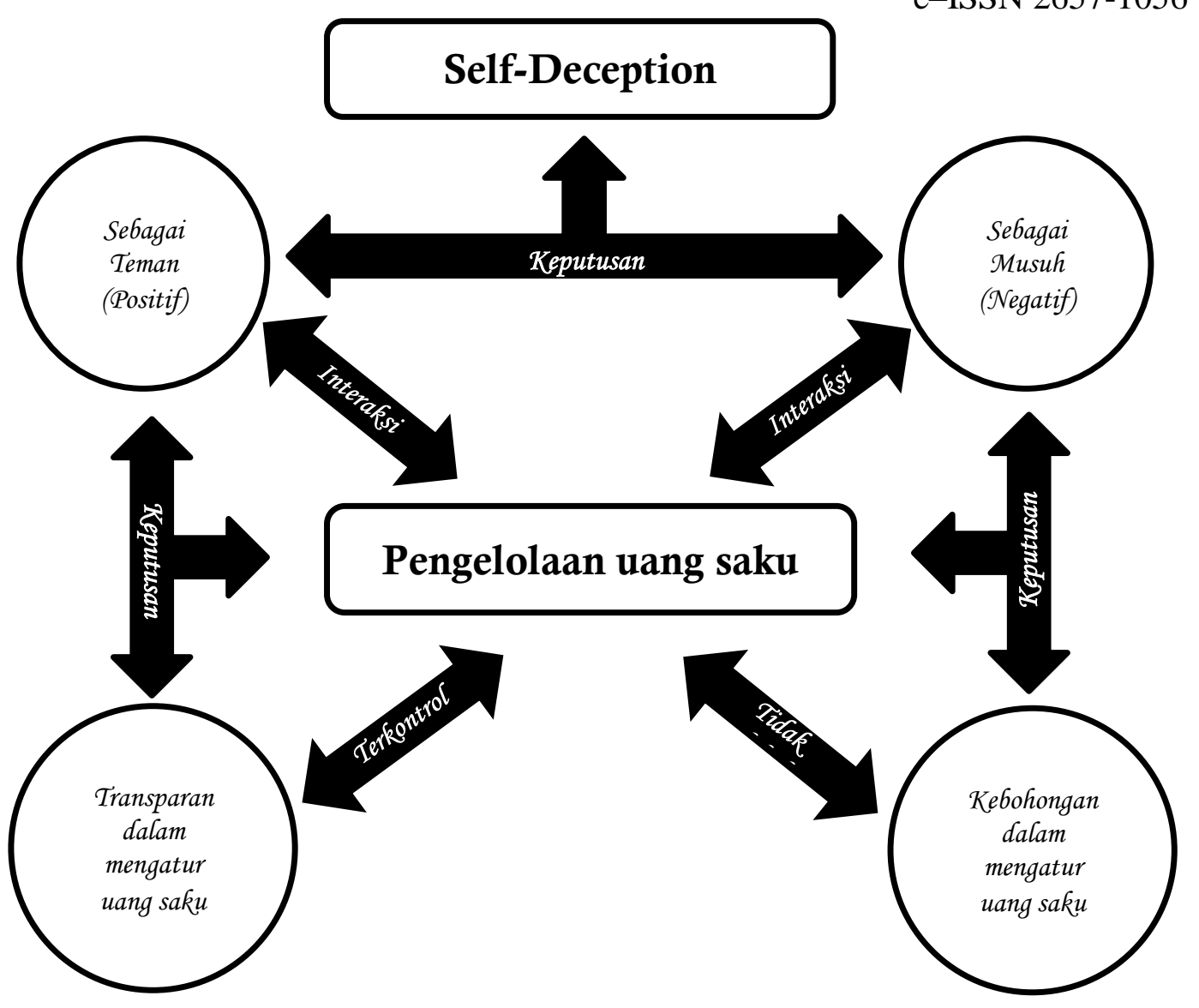

Gambar 2. Konsep Interaksi antara Self-deception dan Pengelolaan Uang Saku $\mathrm{Ha}_{2}$ : Terdapat pengaruh self-deception terhadap pengelolaan uang saku

\section{METODE}

Penelitian ini adalah penelitian kuantitatif dengan jenis penelitian asosiatif. Penelitian dilakukan di Universitas Indraprasta PGRI Jakarta pada bulan april juni 2019. Populasi dan sampel pada penelitian ini adalah mahasiswa pendidikan ekonomi Universitas Indraprasta PGRI Jakarta. Jumlah partisipan dalam penelitian ini sebanyak 219 mahasiswa. Teknik pengumpulan data menggunakan angket (kuesioner) secara langsung dan tidak langsung (via google form). Teknik analisis data menggunakan regresi linear berganda dengan bantuan SPSS versi 24.0.

\section{HASIL DAN PEMBAHASAN}

Hasil penelitian dan pembahasan dikemukakan oleh penulis berdasarkan kajian teori dan empiris serta temuan-temuan. Hasil penelitian dan pembahasan dilakukan secara komprehensif dan dikaji secara detail dan praktis. 
Research and Development Journal Of Education

Vol. 6 No. 1 Oktober 2019

1. Uji Asumsi Klasik

a. Uji Normalitas

Tabel 1. One-Sample Kolmogorov-Smirnov Test

\begin{tabular}{|c|c|c|c|}
\hline \multicolumn{2}{|c|}{ Model } & Unstandardized Residual & Keterangan \\
\hline \multicolumn{2}{|c|}{$\mathrm{N}$} & 219 & \\
\hline \multirow{2}{*}{ Normal Parameters } & Mean & ,0000000 & \\
\hline & Std. Deviation & 4,89276392 & \\
\hline \multirow{3}{*}{$\begin{array}{c}\text { Most Extreme } \\
\text { Differences }\end{array}$} & Absolute &, 033 & Data Terdistribusi \\
\hline & Positive & 033 & Normal \\
\hline & Negative &,- 030 & \\
\hline \multicolumn{2}{|c|}{ Test Statistic } &, 033 & \\
\hline \multicolumn{2}{|c|}{ Asymp. Sig. (2-tailed) } & 200 & \\
\hline
\end{tabular}

\section{b. Uji Homogenitas}

Tabel 2. Test of Homogeneity of Variances

\begin{tabular}{cccccc}
\hline Variabel & Lavene Statistic & df1 & df2 & Sig & Keterangan \\
\hline X1 Terhadap Y &, 736 & 21 & 193 &, 792 & Homogen \\
X2 Terhadap Y &, 616 & 26 & 191 &, 928 & Homogen \\
\hline Sumber
\end{tabular}

Sumber : Hasil Output SPSS 24.0 Tahun 2019

\section{c. Uji Linearitas}

Tabel 3. Statistics Linearity Test

\begin{tabular}{cccc}
\hline Variabel & F $_{\text {hitung }}$ & Sig. & Keterangan \\
\hline X1 Terhadap Y & 1.360 & .131 & Linear \\
X2 Terhadap Y & .931 & .565 & Linear \\
\hline
\end{tabular}

Sumber : Hasil Output SPSS 24.0 Tahun 2019

\section{d. Uji Multikolinearitas}

Tabel 4. Hasil Uji Multikolinearitas

\begin{tabular}{cccc}
\hline Variabel & Tolerance & VIF & Keterangan \\
\hline Self-Knowledge &, 717 & 1,395 & Tidak ada Multikolinieritas \\
Self-Deception &, 717 & 1,395 & Tidak ada Multikolinieritas \\
\hline
\end{tabular}

Sumber : Hasil Output SPSS 24.0 Tahun 2019

\section{e. Uji Autokorelasi}

Tabel 5. Runs Test

\begin{tabular}{ccc}
\hline Model & Unstandardized Residual & Keterangan \\
\cline { 1 - 2 } Test Value &, 03565 & \\
\cline { 1 - 2 } Cases $<$ Test Value & 109 \\
\hline Cases $>$ Test Value & 110 \\
\hline Total Cases & 219 \\
\hline Number of Runs & 101 \\
Z & $-1,287$ \\
Asymp. Sig. (2-tailed) &, 198 \\
\hline Sumber : Hasil Output SPSS 24.0 Tahun 2019
\end{tabular}

Sumber : Hasil Output SPSS 24.0 Tahun 2019 
Research and Development Journal Of Education

Vol. 6 No. 1 Oktober 2019

p-ISSN 2406-9744

e-ISSN 2657-1056

\section{Regresi Linear Berganda}

\section{a. Secara Parsial}

Analisis data secara parsial menggunakan rumus uji t dengan bantuan program SPSS 24.0 for windows. Hasil output dapat dilihat pada tabel berikut ini:

Tabel 6. Hasil Uji t

\begin{tabular}{|c|c|c|c|c|c|c|}
\hline \multirow[t]{2}{*}{ Model } & & \multicolumn{2}{|c|}{$\begin{array}{c}\text { Unstandardized } \\
\text { Coefficients }\end{array}$} & \multirow{2}{*}{$\begin{array}{c}\begin{array}{c}\text { Standardized } \\
\text { Coefficients }\end{array} \\
\text { Beta } \\
\end{array}$} & \multirow[t]{2}{*}{$\mathbf{T}$} & \multirow[t]{2}{*}{ Sig. } \\
\hline & & B & Std. Error & & & \\
\hline \multirow[t]{7}{*}{1} & (Constant) & 38,413 & 3,468 & & 11,076 &, 000 \\
\hline & Self-Knowledge &, 727 &, 080 & 617 & 9,103 &, 000 \\
\hline & Self-Deception &,- 198 & ,067 &,- 201 & $-2,967$ & 003 \\
\hline & $\mathrm{R}$ & & & ,538 & & \\
\hline & R Square & & & ,289 & & \\
\hline & Adjusted R Square & & & ,282 & & \\
\hline & Std. Error of the Estimate & & & 4,915 & & \\
\hline
\end{tabular}

Dependent Variable: Pengelolaan Uang Saku

Sumber : Hasil Output SPSS 24.0 Tahun 2019

Dari hasil uji regresi linear berganda diperoleh nilai $\mathrm{Y}=38,413+0,727 \mathrm{X}_{1}$ - 0,198 $X_{2}$. Koefisien determinan sebesar 0,289 dan dikategorikan lemah. Hal ini menunjukkan bahwa kontribusi variabel self-knowledge $\left(\mathrm{X}_{1}\right)$ dan self-deception $\left(\mathrm{X}_{2}\right)$ terhadap variabel pengelolaan uang saku $(\mathrm{Y})$ sebesar $28,9 \%$, sedangkan $71,1 \%$ dipengaruhi oleh variabel lain. Tabel 6 juga menunjukkan beberapa hasil yang akan dijelaskan sebagai berikut:

1) Pengaruh self-knowledge terhadap pengelolaan uang saku

Hasil koefisien variabel self-knowledge terhadap pengelolaan uang saku diperoleh $t_{\text {hitung }} 9,103 \geq \mathrm{t}_{\text {tabel }} 1,971$ dengan nilai signifikansi $0,000<0,050$, hal ini menunjukkan bahwa $\mathrm{H}_{0}$ ditolak dan $\mathrm{Ha}_{1}$ diterima. Artinya, terdapat pengaruh selfknowledge terhadap pengelolaan uang saku secara signifikan. Hasil koefisien regresi untuk variabel self-knowledge diketahui sebesar 0,617 dengan nilai positif yang artinya self-knowledge mempunyai peran positif untuk membantu individu dalam mengelola uang saku.

Adanya pengaruh self-knowledge terhadap pengelolaan uang saku dikarenakan pengetahuan membantu pola pikir inividu menjadi lebih terarah. Selfknowledge berkontribusi pada aktivitas yang kuat, dinamis, serta memungkinkan individu untuk memutuskan pengelolaan uang saku yang tepat (Woo et al., 2017). Self-knowledge juga dapat berperan sebagai keahlian yang bernilai strategis 
Research and Development Journal Of Education

Vol. 6 No. 1 Oktober 2019

p-ISSN 2406-9744

e-ISSN 2657-1056

(Laihonen, 2006). Oleh karena itu, self-knowledge berdampak positif terhadap pengelolaan uang saku.

2) Pengaruh self-deception terhadap pengelolaan uang saku

Hasil koefisien variabel self-deception terhadap pengelolaan uang saku diperoleh $t_{\text {hitung }} \quad-2,967 \leq t_{\text {tabel }}-1,971$ dengan nilai signifikansi $0,003<0,050$, hal ini menunjukkan bahwa $\mathrm{H}_{0}$ ditolak dan $\mathrm{Ha}_{2}$ diterima. Artinya, terdapat pengaruh negatif self-deception terhadap pengelolaan uang saku secara signifikan. Pengaruh negatif self-deception pada pengelolaan uang saku menunjukkan keterlibatan emosional yang mengarahkan diri individu sebagai manipulasi negatif untuk meningkatkan aktivitas keuangan secara berhati-hati atau waspada (Gomes \& Frade, 2019; Scott, 2012).

Menurut Triandis (2015) hal ini sangat wajar karena jika individu memiliki terlalu banyak self-deception, secara kognitif tidak baik bagi dirinya. Secara tidak sadar mereka akan termotivasi dan berpotensi maladaptif dalam kondisi tertentu (Kuntz \& Dehlin, 2019), serta akan meruskan kesehatan fisik dan mental, harapan hidup, kebahagiaan, dan perlindungan/keamanan (Leung, 2010). Oleh karena itu, self-deception semakin negatif akan semakin baik.

\section{b. Secara Simultan}

Analisis data secara simultan menggunakan rumus uji f dengan bantuan program SPSS 24.0 for windows. Hasil output dapat dilihat pada tabel berikut ini:

Tabel 7. Hasil Uji F

\begin{tabular}{ccc|c|c|c|c}
\multicolumn{2}{l}{ Model } & Sum of Squares & df & Mean Square & F & Sig. \\
\hline \multirow{2}{*}{1} & Regression & 2120,592 & 2 & 1060,296 & 43,885 &, 000 \\
\cline { 2 - 7 } & Residual & 5218,732 & 216 & 24,161 & & \\
\cline { 2 - 7 } & Total & 7339,324 & 218 & & & \\
\hline
\end{tabular}

Dependent Variable: Pengelolaan Uang Saku

Predictors: (Constant), Self-Knowledge, Self-Deception

Sumber : Hasil Output SPSS 24.0 Tahun 2019

Berdasarkan tabel 7 diketahui nilai $F_{\text {hitung }} 43,885 \geq \mathrm{F}_{\text {tabel }} 2,645$ dengan nilai signifikansi $0,000<0,050$, maka $\mathrm{H}_{0}$ ditolak dan $\mathrm{Ha}_{3}$ diterima. Artinya terdapat pengaruh self-knowledge dan self-deception terhadap pengelolaan uang saku 
Research and Development Journal Of Education

Vol. 6 No. 1 Oktober 2019

p-ISSN 2406-9744

e-ISSN 2657-1056

secara siginifikan. Kontribusi self-knowledge dan self-deception pada pengelolaan uang saku terlihat pada kemampuan analisa dan keputusan dalam bertindak (Scott, 2012; Woo et al., 2017).

\section{SIMPULAN}

Berdasarkan hasil dan pembahasan dapat disimpulkan bahwa; 1) terdapat pengaruh self-knowledge terhadap pengelolaan uang saku secara signifikan, 2) terdapat pengaruh self-deception terhadap pengelolaan uang saku secara signifikan, 3) terdapat pengaruh self-knowledge dan self-deception terhadap pengelolaan uang saku secara signifikan. Adapun saran yang dapat diberikan yaitu; 1) untuk peneliti selanjutnya diharapkan dapat menggunakan indikator lain untuk menambah khasanah ilmu pengetahuan, 2) diharapkan menggunakan variabel lain atau membandingankan variabel ini dengan variabel psikologis lainnya, 3) hasil penelitian ini diharapkan dapat menjadi rujukan siswa, mahasiswa, orang tua atau bahkan masyarakat luas.

\section{DAFTAR PUSTAKA}

Anakwe, U. P., Hall, J. C., \& Schor, S. M. (2000). Knowledge-related skills and effective career management. International Journal of Manpower, 21(7), 566-579. https://doi.org/10.1108/01437720010379024

Bachkirova, T. (2016). A new perspective on self-deception for applied purposes. New Ideas in Psychology, 43, 1-9. https://doi.org/10.1016/j.newideapsych.2016.02.004

Begley, P. T. (2006). Self-knowledge, capacity and sensitivity. Journal of Educational Administration, 44(6), 570-589. https://doi.org/10.1108/09578230610704792

Bucciol, A., \& Veronesi, M. (2014). Teaching children to save: What is the best strategy for lifetime savings? Journal of Economic Psychology, 45, 1-17. https://doi.org/http://dx.doi.org/10.1016/j.joep.2014.07.003

Dings, R. (2017). Social strategies in self-deception. New Ideas in Psychology, 47, 16-23. https://doi.org/10.1016/j.newideapsych.2017.03.011

Fuchs, C., \& Hofkirchner, W. (2005). Self-organization, knowledge and responsibility. Kybernetes, 34(1-2), 241-260. https://doi.org/10.1108/03684920510575825

Glanz, L., \& Sluis, E. C. Van Der. (2001). Employing organisations and expatriate spouses: Balancing self-knowledge and knowledge about options. Career Development International, 6(3), 169-176. https://doi.org/10.1108/13620430110389757

Gomes, O., \& Frade, J. (2019). “Fool me once, ...”: deception, morality and selfregeneration in decentralized markets. Journal of Economics, Finance and 
Research and Development Journal Of Education

Vol. 6 No. 1 Oktober 2019

p-ISSN 2406-9744

e-ISSN 2657-1056

Administrative Science. https://doi.org/10.1108/JEFAS-04-2018-0032

Kuntz, J., \& Dehlin, E. (2019). Friend and foe? Self-deception in organisations. Journal of Management Development, 38(2). https://doi.org/10.1108/JMD04-2018-0122

Laihonen, H. (2006). Knowledge flows in self-organizing processes. Journal of Knowledge Management, 10(4), 127-135. https://doi.org/10.1108/13673270610679417

Leung, K. (2010). Self-deception and the ideal culture: Implications for international management research. The Past, Present and Future of International Business \& Management (Vol. 23). Elsevier. https://doi.org/10.1108/S1571-5027(2010)0000023008

Meltzer, B. N. (2003). Lying: Deception in Human Affairs, 23(6), 61-79.

Otto, A. (2013). Saving in childhood and adolescence: Insights from developmental psychology. Economics of Education Review, 33, 8-18. https://doi.org/10.1016/j.econedurev.2012.09.005

Scott, S. (2012). Intimate Deception in Everyday Life. In Studies in Symbolic Interaction (Vol. 39, pp. 251-279). Emerald Group Publishing Ltd. https://doi.org/10.1108/S0163-2396(2012)0000039011

Shumack, K. (2007). Conversations with the self-knowledge creation for designing. Kybernetes, 36(9/10), 1515-1528. https://doi.org/10.1108/03684920710827454

Triandis, H. C. (2015). From culture and behavior to culture and self-deception. The Past, Present and Future of International Business \& Management (Vol. 23). Elsevier. https://doi.org/10.1108/S1571-5027(2010)0000023006

Tully, R. J., \& Bailey, T. (2017). Validation of the Paulhus Deception Scales (PDS) in the UK and examination of the links between PDS and personality. Journal of Criminological Research, Policy and Practice, 3(1), 38-50. https://doi.org/10.1108/JCRPP-10-2016-0027

Vhalery, R., \& Aimon, H. (2018). The Management of Student's Pocket Money.

Vhalery, R., Leksono, A. W., \& Irvan, M. Factors that Influence the Allowance Management. Behaviour, 876(1,000), 0-718.

Vhalery, R., Leksono, A. W., \& Irvan, M. (2019). PENGARUH LITERASI KEUANGAN, USIA, DAN BIMBINGAN ORANG TUA TERHADAP PENGELOLAAN UANG SAKU MAHASISWA UNINDRA. Jurnal Pendidikan Ekonomi, 12(1), 10-17.

Woo, V. C. Y., Boland, R. J., \& Cooperrider, D. L. (2017). Thriving Transitional Experiences: Self-Knowledge, Improvisation, and Transformation Quotient in a Highly Dynamic World. In Human Capital and Assets in the Networked World (pp. 87-150). Emerald Publishing Limited. https://doi.org/10.1108/978-1-78714-827-720171005 
Research and Development Journal Of Education

Vol. 6 No. 1 Oktober 2019

p-ISSN 2406-9744

e-ISSN 2657-1056

\section{Lampiran}

Variabel Self-Deception

\begin{tabular}{|c|c|c|c|c|c|}
\hline No. & $\begin{array}{l}\text { Pernyataan } \\
\end{array}$ & Pearson Correlation & Sig. (2-tailed) & Validitas & Reliabilitas \\
\hline 1. & $\begin{array}{l}\text { Kesan pertama saya tentang tata cara mengelola } \\
\text { uang orang lain biasanya benar }\end{array}$ & 0,344 & 0,009 & Valid & \\
\hline 2.* & $\begin{array}{l}\text { Akan sulit bagi saya untuk menghentikan } \\
\text { kebiasaan buruk dalam menghabiskan uang }\end{array}$ & 0,305 & 0,021 & Valid & \\
\hline 3. & $\begin{array}{l}\text { Saya tidak peduli dengan pendapat orang lain } \\
\text { tentang tata cara saya dalam mengatur uang }\end{array}$ & 0,573 & 0,000 & Valid & \\
\hline 4. ${ }^{*}$ & Saya tidak selalu tepat dalam mengatur uang & 0,563 & 0,000 & Valid & \\
\hline 5. & $\begin{array}{l}\text { Saya selalu tahu mengapa saya suka banyak hal } \\
\text { yang berkaitan dengan keuangan }\end{array}$ & 0,380 & 0,004 & Valid & \\
\hline $6 . *$ & $\begin{array}{l}\text { Ketika emosi saya terangsang, semua perhitungan } \\
\text { keuangan saya menjadi bias }\end{array}$ & 0,537 & 0,000 & Valid & \\
\hline 7. & $\begin{array}{l}\text { Setelah saya memutuskan, orang lain tidak dapat } \\
\text { mengubah pembukuan saya }\end{array}$ & 0,538 & 0,000 & Valid & \\
\hline 8.* & $\begin{array}{l}\text { Saya bukan pencatat keuangan yang baik ketika } \\
\text { saya diluar batas }\end{array}$ & 0,452 & 0,000 & Valid & \\
\hline 9. & $\begin{array}{l}\text { Saya sepenuhnya mengendalikan nasib keuangan } \\
\text { saya sendiri }\end{array}$ & 0,600 & 0,000 & Valid & \\
\hline $10 * *$ & $\begin{array}{l}\text { Sulit bagi saya untuk menstabilkan keuangan } \\
\text { disaat ada yang mengganggu pikiran }\end{array}$ & 0,461 & 0,000 & Valid & \\
\hline 11. & $\begin{array}{l}\text { Saya tidak pernah menyesali keputusan keuangan } \\
\text { saya }\end{array}$ & 0,352 & 0,007 & Valid & \\
\hline 12. * & $\begin{array}{l}\text { Kadang-kadang saya kehilangan banyak hal } \\
\text { karena saya tidak bisa segera mengambil } \\
\text { keputusan keuangan }\end{array}$ & 0,547 & 0,000 & Valid & Reliabel \\
\hline 13. & $\begin{array}{l}\text { Alasan saya memilih menabung adalah karena } \\
\text { tabungan saya dapat membuat perbedaan dimasa } \\
\text { mendatang }\end{array}$ & 0,590 & 0,000 & Valid & \\
\hline 14. * & $\begin{array}{l}\text { Orang seperti dia (teman main/teman } \\
\text { kantor/kenalan) tidak memperhatikan saya dan } \\
\text { kemampuan saya dalam mengatur keuangan }\end{array}$ & $-0,090$ & 0,506 & Tidak Valid & \\
\hline 15. & $\begin{array}{l}\text { Saya orang yang sepenuhnya rasional dalam } \\
\text { mengatur keuangan }\end{array}$ & 0,527 & 0,000 & Valid & \\
\hline 16. * & $\begin{array}{l}\text { Saya jarang menghargai kritik orang tentang cara } \\
\text { mengelola uang saya }\end{array}$ & 0,191 & 0,154 & Tidak Valid & \\
\hline 17. & $\begin{array}{l}\text { Saya sangat yakin akan penilaian saya terhadap } \\
\text { keuangan seseorang }\end{array}$ & 0,207 & 0,123 & Tidak Valid & \\
\hline 18. * & $\begin{array}{l}\text { Saya terkadang meragukan kemampuan saya } \\
\text { sebagai teman yang memberikan arahan } \\
\text { keuangan }\end{array}$ & 0,239 & 0,073 & Tidak Valid & \\
\hline 19. & $\begin{array}{l}\text { Tidak masalah bagi saya jika beberapa orang } \\
\text { tidak menyukai cara saya mengelola uang }\end{array}$ & 0,367 & 0,005 & Valid & \\
\hline 20. * & $\begin{array}{l}\text { Saya hanya orang biasa yang mengatur keuangan } \\
\text { secara terstruktur }\end{array}$ & $-0,079$ & 0,558 & Tidak Valid & \\
\hline
\end{tabular}


Research and Development Journal Of Education

Vol. 6 No. 1 Oktober 2019

p-ISSN 2406-9744

e-ISSN 2657-1056

Variabel Self-Knowledge

\begin{tabular}{|c|c|c|c|c|c|}
\hline No. & Pernyataan & Pearson Correlation & Sig. (2-tailed) & Validitas & Reliabilitas \\
\hline 1. & Saya mengetahui batas kemampuan keuangan saya & 0,493 & 0,000 & Valid & \multirow{12}{*}{ Reliabel } \\
\hline 2. & Saya mempunyai informasi keuangan yang sangat baik & 0,400 & 0,002 & Valid & \\
\hline $3 . *$ & Saya tidak memiliki pengetahuan di bidang keuangan & 0,489 & 0,000 & Valid & \\
\hline 4. & Saya dapat mengendalikan keuangan disaat yang tepat & 0,571 & 0,000 & Valid & \\
\hline 5. & $\begin{array}{l}\text { Saya akan mencari data untuk mendukung kemampuan } \\
\text { keuangan saya }\end{array}$ & 0,440 & 0,001 & Valid & \\
\hline 6. & $\begin{array}{l}\text { Saya dapat menganalisa keuangan masuk dan keuangan } \\
\text { keluar setiap waktu }\end{array}$ & 0,472 & 0,000 & Valid & \\
\hline 7.* & $\begin{array}{l}\text { saya tidak dapat menstabilkan pemasukan dan } \\
\text { pengeluaran }\end{array}$ & 0,382 & 0,003 & Valid & \\
\hline 8. & saya tahu kapan harus memulai menabung & 0,609 & 0,000 & Valid & \\
\hline 9.* & $\begin{array}{l}\text { saya tidak tahu kapan waktu yang tepat untuk } \\
\text { menyimpan uang }\end{array}$ & 0,458 & 0,000 & Valid & \\
\hline 10. & $\begin{array}{l}\text { memulai mengelola uang sejak dini dapat } \\
\text { menyelamatkan saya dimasa tua }\end{array}$ & 0,591 & 0,000 & Valid & \\
\hline 11. & $\begin{array}{l}\text { membiasakan diri dengan keuangan akan menjadikan } \\
\text { saya pengatur keuangan yang baik }\end{array}$ & 0,581 & 0,000 & Valid & \\
\hline 12.* & $\begin{array}{l}\text { suatu waktu, saya pernah tidak menyadari kemana uang } \\
\text { saya dialokasikan }\end{array}$ & 0,324 & 0,014 & Valid & \\
\hline
\end{tabular}

Variabel Pengelolaan Uang Saku

\begin{tabular}{|c|c|c|c|c|c|}
\hline No. & $\begin{array}{l}\text { Pernyataan } \\
\end{array}$ & Pearson Correlation & Sig. (2-tailed) & Validitas & Reliabilitas \\
\hline 1. & Saya mencatat uang saku yang saya terima & 0,633 & 0,000 & Valid & \multirow{19}{*}{ Reliabel } \\
\hline 2. & Saya membuat laporan uang saku secara sederhana & 0,657 & 0,000 & Valid & \\
\hline $3 . *$ & Saya memiliki rencana keuangan untuk kedepan & 0,586 & 0,000 & Valid & \\
\hline 4. & Saya mematuhi rencana keuangan yang telah saya buat & 0,353 & 0,007 & Valid & \\
\hline 5. & Saya membuat tujuan uang saku yang harus dicapai & 0,512 & 0,000 & Valid & \\
\hline 6. & Saya membuat daftar kebutuhan yang akan dibeli & 0,535 & 0,000 & Valid & \\
\hline 7.* & Saya membuat daftar belanja mingguan/bulanan & 0,506 & 0,000 & Valid & \\
\hline 8. & $\begin{array}{l}\text { Saya mengikuti anggaran belanja yang telah saya } \\
\text { buat }\end{array}$ & 0,676 & 0,000 & Valid & \\
\hline 9.* & Saya menggunakan uang saku seefisien mungkin & 0,465 & 0,000 & Valid & \\
\hline 10. & $\begin{array}{l}\text { Saya menggunakan sebagian uang untuk keperluan } \\
\text { sekolah/kampus }\end{array}$ & 0,527 & 0,000 & Valid & \\
\hline 11. & Saya mencatat semua biaya pengeluaran & 0,650 & 0,000 & Valid & \\
\hline $12 .^{*}$ & $\begin{array}{l}\text { Ketika berbelanja saya hanya berbelanja yang saya } \\
\text { butuhkan }\end{array}$ & 0,504 & 0,000 & Valid & \\
\hline 13. & Saya membelanjakan uang diakhir periode sampai habis & 0,304 & 0,021 & Valid & \\
\hline 14. & $\begin{array}{l}\text { Ketika berbelanja saya mendahulukan keinginan } \\
\text { daripada kebutuhan }\end{array}$ & 0,252 & 0,059 & Tidak Valid & \\
\hline 15. & Saya membuat daftar kebutuhan yang akan dibeli & 0,470 & 0,000 & Valid & \\
\hline 16. & $\begin{array}{l}\text { Saya menyisihkan sebagian uang saku untuk hal-hal } \\
\text { yang tidak terduga }\end{array}$ & 0,522 & 0,000 & Valid & \\
\hline 17. & Saya memiliki rekening dan saldo di bank & 0,562 & 0,000 & Valid & \\
\hline 18 & Saya menabung dirumah & 0,139 & 0,303 & Tidak Valid & \\
\hline 19. & Saya mengikuti asuransi & 0,524 & 0,000 & Valid & \\
\hline
\end{tabular}

